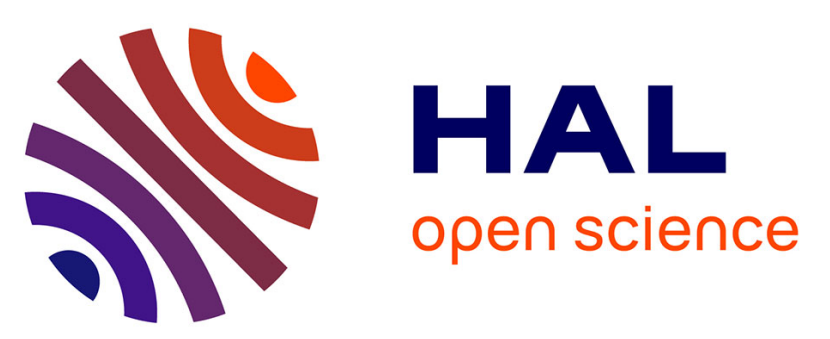

\title{
A scientific note on the impact of acaracides on the nutritional biochemistry of Apis mellifera intermissa (Hymenoptera: Apidae)
}

Wahida Loucif-Ayad, Nadia Aribi, Guy Smagghe, Noureddine Soltani

\section{- To cite this version:}

Wahida Loucif-Ayad, Nadia Aribi, Guy Smagghe, Noureddine Soltani. A scientific note on the impact of acaracides on the nutritional biochemistry of Apis mellifera intermissa (Hymenoptera: Apidae). Apidologie, 2010, 41 (2), 10.1051/apido/2009063 . hal-00891970

\section{HAL Id: hal-00891970 https://hal.science/hal-00891970}

Submitted on 1 Jan 2010

HAL is a multi-disciplinary open access archive for the deposit and dissemination of scientific research documents, whether they are published or not. The documents may come from teaching and research institutions in France or abroad, or from public or private research centers.
L'archive ouverte pluridisciplinaire HAL, est destinée au dépôt et à la diffusion de documents scientifiques de niveau recherche, publiés ou non, émanant des établissements d'enseignement et de recherche français ou étrangers, des laboratoires publics ou privés. 


\title{
A scientific note on the impact of acaracides on the nutritional biochemistry of Apis mellifera intermissa (Hymenoptera: Apidae)*
}

\author{
Wahida LOUCIF-AYAD ${ }^{1}$, Nadia ARIBI ${ }^{1}$, Guy SMAGGHE ${ }^{2}$, Noureddine SoltANI ${ }^{1}$ \\ ${ }^{1}$ Laboratory of Applied Animal Biology, Department of Biology, Faculty of Science, University of Annaba, \\ 23000 Annaba, Algeria \\ ${ }^{2}$ Laboratory of Agrozoology, Department of Crop Protection, Faculty of Bioscience Engineering, Ghent University, \\ 9000 Ghent, Belgium
}

Received 18 January 2009 - Revised 23 May 2009 - Accepted 29 May 2009

Apis mellifera intermissa / acaricides / physiology

Colonies of honeybees are susceptible to a number of pests and diseases whose damage has negative economic impacts on the beekeeping industry and agriculture. Varroa destructor is a serious parasitic mite of honeybees worldwide. In general, the control of this mite is obtained by the use of several acaricides. Little has been reported on the sideeffects of these treatments on honeybees (Haarmann et al., 2002; Gregorc et al., 2007) and there has been no research on the biochemical effects on the host after exposure to acaracides. Likewise, more studies on these acaricides are needed to evaluate their possible negative effects on the honeybee populations. The aim of this work was to determine secondary effects of four acaricides treatments on the metabolism of the bees by measuring the amounts of protein, carbohydrates and lipids in the hemolymph and body tissues of newly emerged worker bees, nurses and forager bees. The four acaracides tested were two synthetic compounds Bayvarol and Apivar and two naturally derived treatments, Apiguard and ApiLife Var.

The experiments were carried out in an apiary of honeybees derived from Apis mellifera intermissa during September-October 2006 in eastern Algeria (Annaba: $36^{\circ} 55^{\prime} \mathrm{N} 7^{\circ} 39^{\prime} \mathrm{E}$ ). Five groups (acaricide treatments and control) of three hives each were used. Acaricides were applied after the honey had been harvested and as recommended by the manufacturers. The treatments were applied from the egg to the adult stage in order to sample adult workers

Corresponding author: N. Soltani, nsolt@yahoo.fr

* Manuscript editor: Yves Le Conte that had been exposed to acaricides during their development. Two plastic strips of Apivar (500 mg of amitraz per strip) were inserted in the brood chamber of each hive. Four strips (3.6 mg of flumethrin per strip) were inserted in the brood chamber of each hive. Strips of Apivar and Bayvarol were left for six weeks and then removed from the treated hives. Apiguard is made with thymol in gelatine manufactured as $50 \mathrm{~g}$ gel portions. One tray of Apiguard (12.5 g of thymol per tray) was placed on the top bars of the frames of each brood nest and a second tray at 15 day intervals. ApiLife Var is composed of a porous ceramic carrier impregnated with a mixture of thymol $(76 \%)$, eucalyptol $(16.4 \%)$, menthol (3.8\%) and camphor (3.8\%). The vermiculite tablet was placed on the upper part of the brood combs. After 3 weeks of application, a second tablet was placed in the hive for the same period (Imdorf et al., 1999).

When the treatments had been on the colonies for 21 days (the duration of development of a worker bee), 12-18 adult bees were sampled from each treatment group when they reached 0,7 , and 21 days of age.

Then amount of protein, carbohydrate and lipid in the whole body and hemolymph of each bee was determined after extraction (Shibko et al., 1966) by spectrophotometric methods of Bradford (1976), Duchateau and Florkin (1959) and Goldsworthy et al. (1972), respectively. The measurements were done without the gastrointestinal tract. No significant differences were found among bees within each treatment group at $P=0.05$. Before applying 

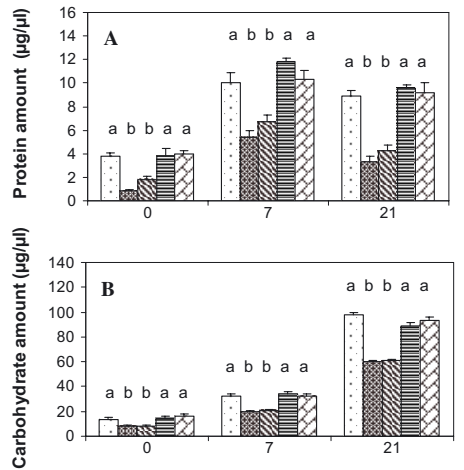

$\square$ Control

图 Apivar

Bayvarol

目 Apiguard

$\square$ ApiLife Var

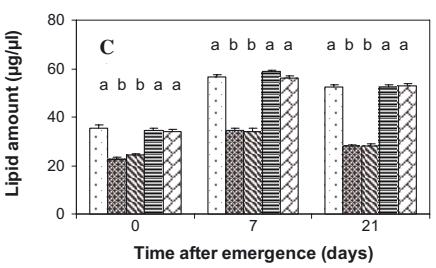

Figure 1. Effects of acaricides on the protein (A), carbohydrate (B) and lipid (C) concentration $(\mu \mathrm{g} / \mu \mathrm{L})$ in the hemolymph during adult maturation of worker honeybees Apis mellifera intermissa. Data are expressed as means \pm SE $(n=12-18)$. For each age group, different letters above bars indicate significant differences at $P<0.05$ (ANOVA followed by a post-hoc Tukey test).

ANOVA, the homogeneity of variances was controlled by the Levene method (Dagnelie, 1998).

Data on the amounts of proteins, carbohydrates and lipids in the hemolymph of $0-, 7$ - and 21-dold workers showed that there was no significant difference among colonies treated with Apiguard, ApiLife Var and untreated colonies (Fig. 1A-C). In contrast, the amounts of hemolymph protein, carbohydrate and lipid were reduced in colonies treated with Bayvarol and Apivar in each of three adult age classes tested. For the body extracts, the protein amounts in newly emerged workers (0-d-old) showed a significant decrease in the groups treated with the synthetic acaricides Bayvarol and Apivar in comparison with the untreated groups and the groups treated with the two thymol formulations (Fig. 2A-C). The negative effect persisted in 7-day old workers. But at 21 days in the adult stage the protein amounts were not statistically different $(P>0.05)$ among all experimental groups. In addition, as shown in Figure 2B, the carbohydrate amounts in whole bodies were not significantly dif-
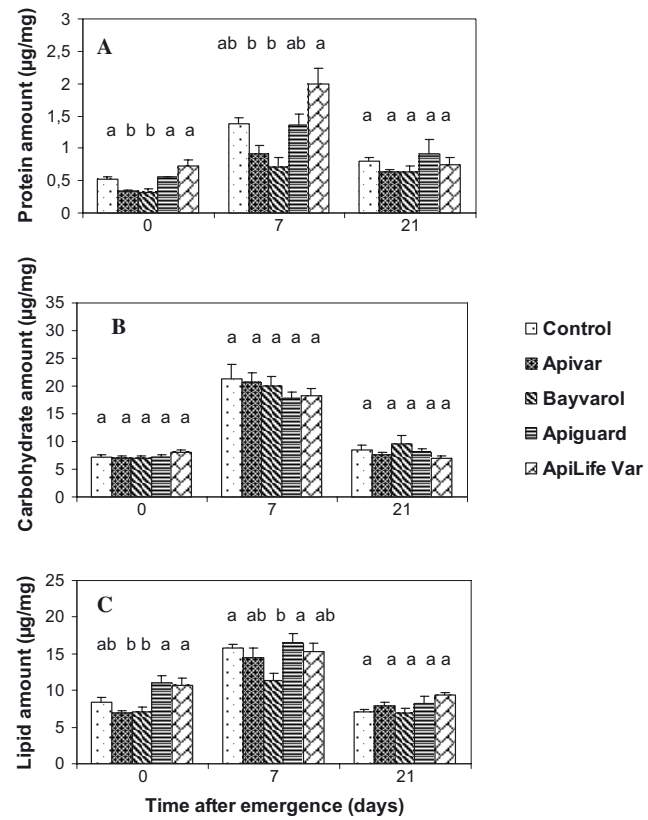

Figure 2. Effects of acaricides on the protein (A), carbohydrate (B) and lipid (C) contents $(\mu \mathrm{g} / \mathrm{mg})$ in the whole body extract during adult maturation of worker honeybees Apis mellifera intermissa. Data are expressed as means $\pm \operatorname{SE}(\mathrm{n}=12-18)$. For each age group, different letters above bars indicate significant differences at $P<0.05$ (ANOVA followed by a post-hoc Tukey test).

ferent in all treated groups compared to the control ( $P>0.05$ for $0-, 7$ - and 21-d-old workers). Finally, the lipid amounts in the total body extracts were significantly different at day $0(P<0.01)$ and 7 $(P<0.05)$ during the adult stage and statistically similar $(P>0.05)$ at day 21 (Fig. 2C).

From these analyses, it was clear that Bayvarol and Apivar caused a considerable decrease in the main biochemical compounds of the hemolymph of adult workers from emergence to foraging age, and to a lower extent in the proteins and lipids in the body tissues of 0- and 7-d-old workers. It is likely that the bees treated with Bayvarol and Apivar did not accumulate hemolymph protein, lipid and carbohydrate amounts to the same extent compared to untreated bees. The therapeutic doses of acaricides were used and it is well known that all of the administrated thymol, or thymol blended with essential oils, is released in the colony, but for amitraz and flumethrin the plastic strips retain part of the active ingredients. In this way, the synthetic treatments 
may have more of an effect on the bees. As workers aged (at day 21), the differences in biochemical amounts in the body tissues had disappeared among the five groups (control, Apivar, Bayvarol, Apiguard, ApiLife Var). We hypothesize that this may be due to the fact that 21-d-old foraging workers were less exposed to the acaricides compared to workers confined in the hive.

The differences in biochemical composition among the honey bee ages may be related to their different functions within the colony, which is reflected in many physiological, morphological and behavioural differences (Hrassinigg and Crailsheim, 2005).

The two thymol formulations ApiLife Var and Apiguard had less effect on the amount of protein, carbohydrates and lipids of the honeybees compared to Apivar and Bayvarol. Further experiments should be conducted to establish the relationship between reduction in the biochemical components detected in the adult workers and acaricides.

Note scientifique sur l'impact des acaricides sur la biochimie nutritionnelle d'Apis mellifera intermissa (Hymenoptera : Apidae).

\section{Eine wissenschaftliche Notiz zum Einfluss von Akariziden auf die Biochemie der Ernährung von Apis mellifera intermissa (Hyme- noptera: Apidae).}

\section{REFERENCES}

Bradford M.M. (1976) A rapid and sensitive method for the quantification of microgram quantities of protein utilizing the principle of protein-dye binding, Anal. Biochem. $72,248-254$

Dagnelie P. (1998) Statistique théorique et appliquée, Inférence statistique à une et à deux dimensions, De Boeck \& Larcier s.a., Bruxelles, pp. 181-186.

Duchateau G., Florkin M. (1959) Sur la trehalosemie des insectes et sa signification, Arch. Insect Biochem. Physiol. 67, 306-314.

Goldsworthy G., Mordue W., Guthkelch J., (1972) Studies on insect adipokinetic hormones, Gen. Comp. Endocr. 18, 545-551.

Gregorc A., Ivana M., Skerl S. (2007) Toxicological and Immunohistochemical testing of honeybees after oxalic acid and rotenone treatments, Apidologie 38, 296-305.

Haarmann T., Spivak M., Weaver D., Weaver B., Glenn T. (2002) Effects of fluvalinate and coumaphos on queen honey bees (Hymenoptera: Apidae) in two commercial queen rearing operations, J. Econ. Entomol. 95, 28-35.

Hrassnigg N., Crailsheim K. (2005) Differences in drone and worker physiology in honeybees (Apis mellifera), Apidologie 36, 255-277.

Imdorf A., Bogdanov S., Ibanez Ochoa R., Calderone N.W. (1999) Use of essential oils for the control of Varroa jacobsoni Oud. in honey bee colonies, Apidologie 30, 209228.

Shibko S., Koivistoinen P., Tratnyek C.A., Newhall A.R., Friedman L. (1966) A method for sequential quantitative separation and determination of protein, RNA, DNA, lipid, and glycogen from a single rat liver homogenate or from a subcellular fraction, Anal. Biochem. 19, 514-528. 